\title{
First Report of Boxwood Blight Caused by Calonectria pseudonaviculata in Florida
}

\begin{abstract}
Fanny Iriarte, Mathews Paret, and Gary Knox, UF/IFAS North Florida Research and Education Center, Quincy 32351; Tim Schubert, Ayyamperumal Jeyaprakash, and David Davison, Florida Department of Agriculture and Consumer Services, Division of Plant Industry, Gainesville 32608
\end{abstract}

Accepted for publication 22 September 2016.

In May 2015, liners of Common boxwood (Buxus sempervirens) and 'Green Velvet' (B. sinica var. insularis $\times$ B. sempervirens 'Suffruticosa') purchased from Oregon and growing at a commercial nursery in North Florida were found with symptoms typical of Boxwood Blight disease. The incidence of symptomatic plants was close to $100 \%$. Symptoms consisted of leaf spot, blighted leaves, and black stem discoloration (Fig. 1), and a large amount of leaf debris at the base of plants (Fig. 2). In a second occurrence (February 2016), a topiary boxwood purchased from a nursery in Cairo, GA, which had obtained it from an Oregon nursery, presented leaf spot and blight similar to Boxwood Blight disease (Fig. 3). This plant had a latent infection: it was asymptomatic when purchased and transported to a residential landscape in Tallahassee, FL.

In both cases, infected plant material was placed in a moist chamber for 6 to 8 days, after which clusters of spores were observed on the stems and on underside of leaves (Fig. 4). Spores were observed under a compound microscope (40x) and identified as Cylindrocladium pseudonaviculatum (asexual stage of Calonectria pseudonaviculata) spores (Fig. 5). For further confirmation, infected tissue was used to extract DNA using a DNeasy QIAGEN plant mini kit and a conventional PCR was performed using $\beta$-tubulin primers (T1, 5'-AACATGCGTGAGA TTGTAAGT-3' and T2, 5'-TAGTGACCCTTGGCCCAGTTG-3') (O'Donnell and Cigelnik 1997). PCR products were purified using the QIAGEN PCR purification kit and sequenced. BLAST analysis of the resulting sequence (GenBank Accession No. KU854867) was shown to have $100 \%$ pairwise identity to a Calonectria pseudonaviculata $\beta$-tubulin gene (Accession No. JX535307). The pathogen was also isolated by plating infected plant material on V8 agar. After 5 to 6 days, genomic DNA was extracted from fungal mycelium also using the DNeasy Plant Mini Kit and amplified through PCR using $\beta$-tubulin primers. The resulting sequence (Accession No. KU854868) was shown to have $100 \%$ pairwise identity to a second Calonectria pseudonaviculata $\beta$-tubulin gene (Accession No. JX535308).

To complete Koch's postulates, Calonectria pseudonaviculata's conidia were produced as previously described (Shishkoff et al. 2015). Conidia were collected in water (with $0.1 \%$ v/v Tween-20 and adjusted to approximately 1000 spores $/ \mathrm{ml})$. Liners of common boxwood and two other cultivars ('Wintergreen' and 'Gregem' [Baby Gem]) were inoculated one by one by dipping

Corresponding author: F. Iriarte. Email: fbiriarte@ufl.edu.

doi:10.1094/PHP-BR-16-0027

(C) 2016 The American Phytopathological Society

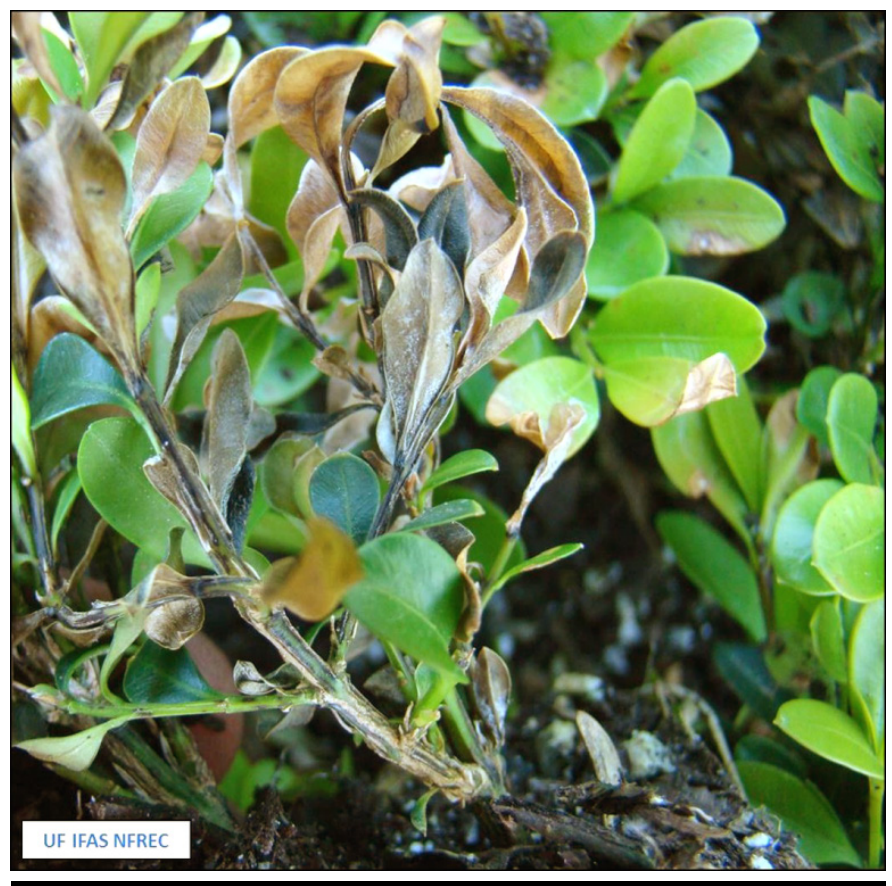

FIGURE 1

Infected $B$. sempervirens liners showing black stem discoloration.

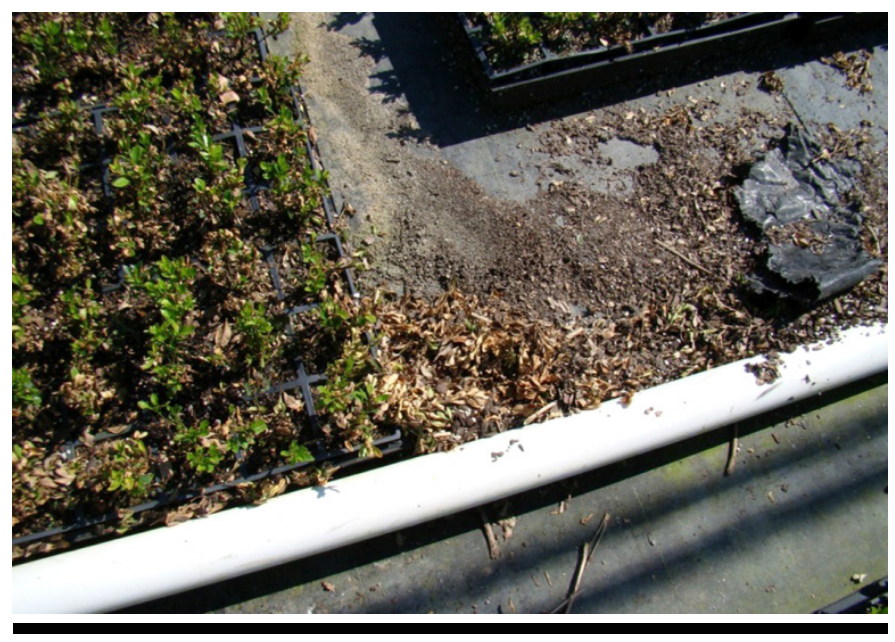

FIGURE 2

Buxus sempervirens liners infected with C. pseudonaviculata. Note large amount of infected leaf litter on the floor. 
entire plants in a 1000-ml beaker containing $500 \mathrm{ml}$ of the spore suspension for $10 \mathrm{sec}$, after which the plants were put back in the starting trays. Liners were maintained under a greenhouse bench mist at 20 to $25^{\circ} \mathrm{C}$ for 2 to 3 weeks at the University of Florida North Florida Research and Education Center (UF-NFREC) quarantine greenhouse. On common boxwood, leaf spots were observed at 7 to 10 days after inoculation, followed by stem blight and leaf drop by 20 to 30 days after inoculation (Fig. 6). Disease developed very slowly on the other two cultivars, resulting in only a few leaf spots even after plants were kept under mist for an additional month. 'Wintergreen' previously was reported to express a low percentage of disease severity (7\%), compared to more susceptible cultivars (up to 80\%) (Ganci et al. 2013). Plants dipped in water remained asymptomatic. To confirm the presence

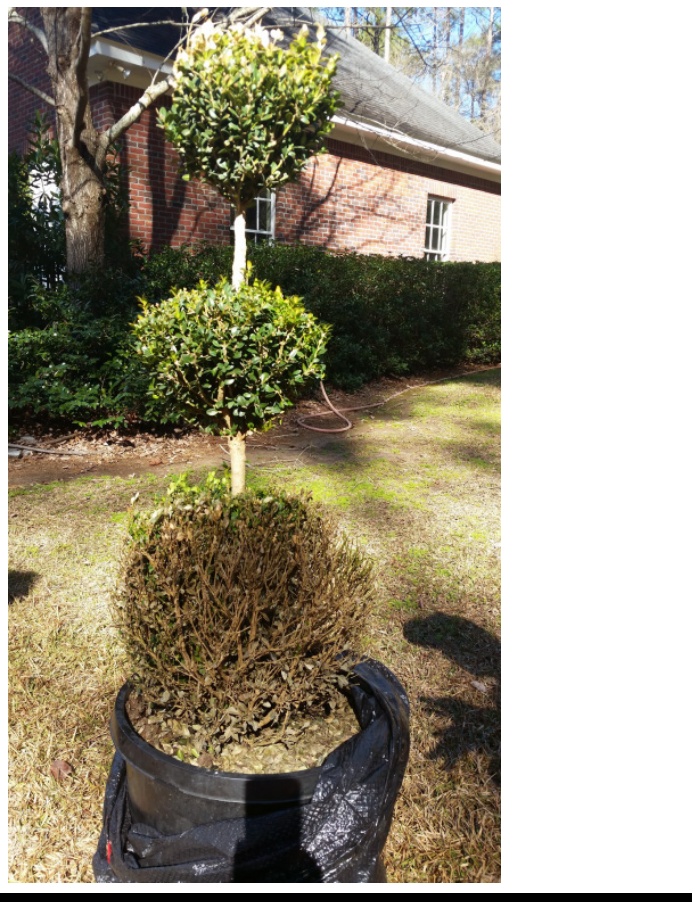

FIGURE 3

Three-ball topiary boxwood showing symptoms of Boxwood blight.

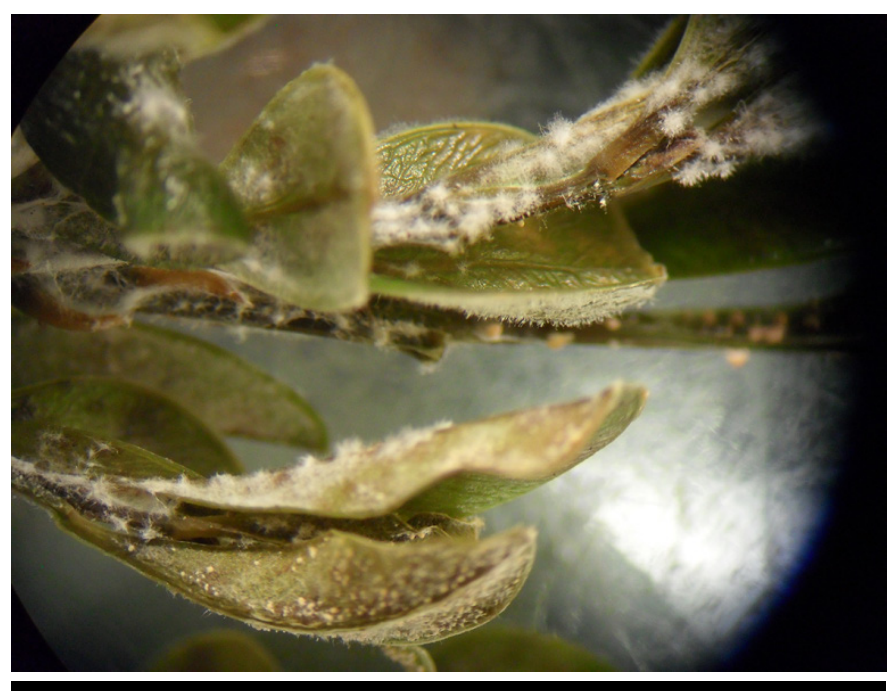

FIGURE 4

Infected Boxwood plant material showing clusters of C. pseudonaviculata's asexual stage spores. of C. pseudonaviculata, plant material presenting leaf spot and blighted stems was sampled and placed in a moist chamber in the laboratory. Clusters of spores typical of the asexual stage of $C$. pseudonaviculata were detected after 5 to 6 days (Fig. 5). The pathogen was recovered from infected plant material cultured on V8-agar media. DNA was extracted from fungal mycelium and amplified using PCR procedures. The resulting sequence was shown to have $100 \%$ pairwise identity to Calonectria pseudonaviculata $\beta$-tubulin gene (GenBank Accession No. JX535308).

To our knowledge, this is the first report of Boxwood blight in Florida. The Florida Department of Agriculture and Consumer Services Division of Plant Industry (FDACS-DPI), the nursery in Quincy, FL, and the homeowner in Tallahassee, FL, implemented strategies to eradicate the pathogen from both locations.

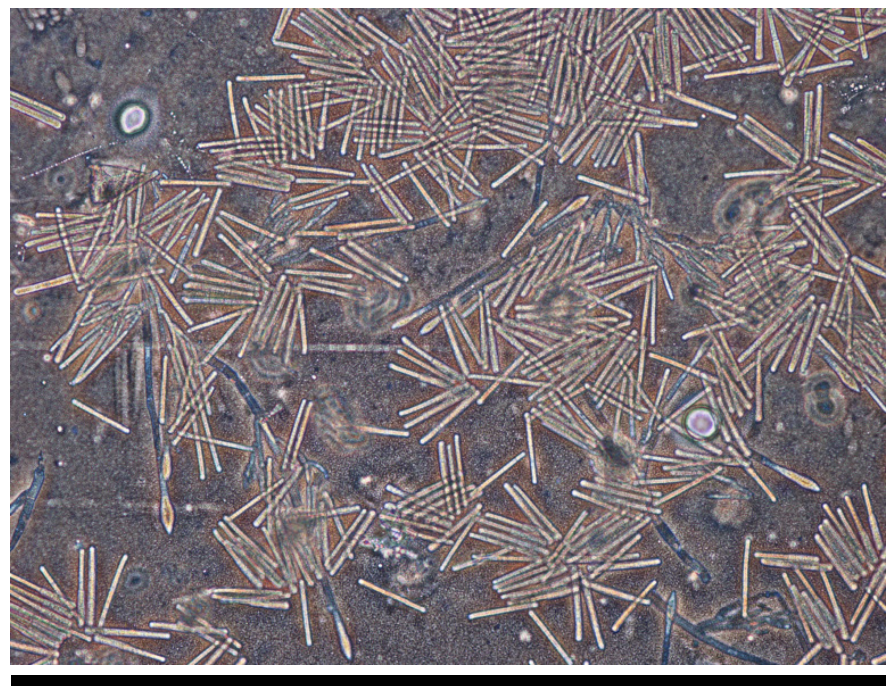

FIGURE 5

Cylindrocladium pseudonaviculata's asexual stage spores (40x magnification).

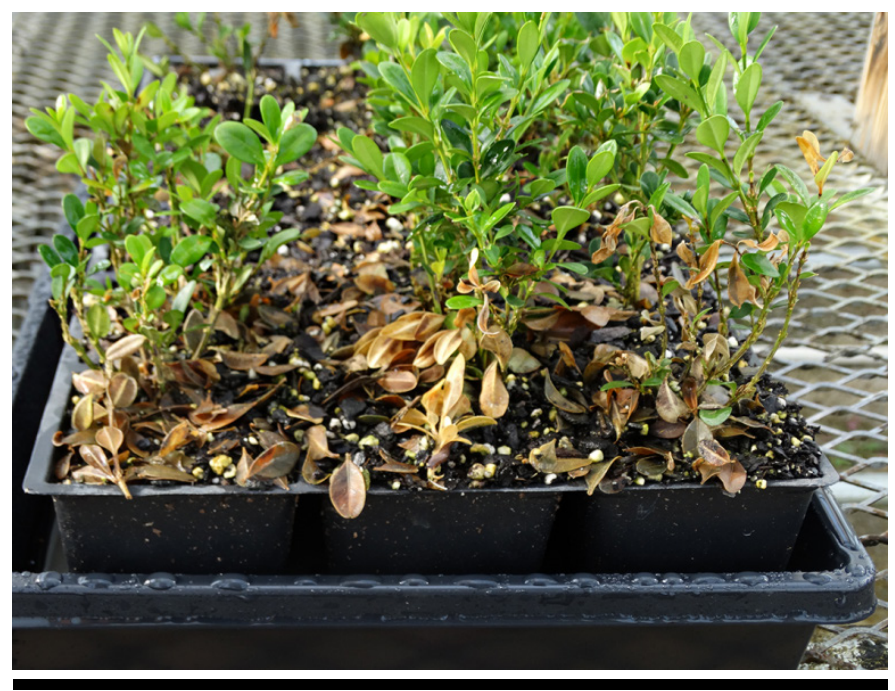

FIGURE 6

Inoculated $B$. sempervirens plants in greenhouse showing symptoms of Boxwood blight. 


\section{LITERATURE CITED}

Ganci, M., Benson, D. M., and Ivors, K. 2013. Susceptibility of commercial boxwood varieties to boxwood blight, 2013. (Boxwood cultivars with tolerance to box blight, 2013). North Carolina Coop. Ext., Plant Pathology, Raleigh. https://plantpathology.ces.ncsu.edu/wp-content/ uploads/2013/05/final-Cult-trials-summary-2013.pdf?fwd=no
O’Donnell, K., and E. Cigelnik. 1997. Two divergent intragenomic rDNA ITS2 types within a monophyletic lineage of the genus Fusarium are nonorthologous. Mol. Phylogenet. Evol. 7:103-116.

Shishkoff, N., Daughtrey, M., Aker, S., and Olsen, R. T. 2014. Evaluating boxwood susceptibility to Calonectria pseudonaviculata using cuttings from the National Boxwood Collection. Plant Health Prog. doi: 10.1094/PHP-RS-14-0033. 